\title{
Bringing Out-of-School Learning into the Classroom: Self- versus Peer-Monitoring of Learning Behaviour
}

\author{
Yelva C. Larsen ${ }^{1, *}$, Jorge Groß ${ }^{2}\left(\mathbb{C}\right.$ and Franz X. Bogner ${ }^{1}$ (1) \\ 1 Department of Biology Education, University of Bayreuth, D-95447 Bayreuth, Germany; \\ franz.bogner@uni-bayreuth.de \\ 2 Department of Science Education, Otto-Friedrich-University of Bamberg, D-96047 Bamberg, Germany; \\ jorge.gross@uni-bamberg.de \\ * Correspondence: yelva.larsen@uni-bamberg.de
}

Received: 7 September 2020; Accepted: 10 October 2020; Published: 16 October 2020

\begin{abstract}
Based on classroom management fostering autonomy support and intrinsic motivation, this study examines effects of reciprocal peer-monitoring of learning behaviours on cognitive and affective outcomes. Within our study, 470 German secondary school students between 13 and 16 years of age participated in a multimodal hands- and minds-on exhibition focusing on renewable resources. Three groups were separated and monitored via a pre-post-follow up questionnaire: the first conducted peer-monitoring with the performance of specific roles to manage students' learning behaviours, the second accomplished a self-monitoring strategy, while the third group did not visit the exhibition. In contrast to the latter control group, both treatment groups produced a high increase in short- and long-term knowledge achievement. The peer-monitored group scored higher in cognitive learning outcomes than the self-monitored group did. Interestingly, the perceived level of choice did not differ between both treatment groups, whereas peer-monitoring increased students' perceived competence and simultaneously reduced the perceived level of anxiety and boredom. Peer-monitoring realised with the performance of specific roles seems to keep students "on task" without lowering indicators for students' intrinsic motivation. Herewith, we are amongst the first to suggest peer-monitoring as a semi-formal learning approach to balance between teacher-controlled instruction and free-choice exploration.
\end{abstract}

Keywords: peer-regulation; self-regulation; peer monitoring; workbook guidance; mobile science centre; semi-formal learning; hands-on learning; intrinsic motivation; autonomy in group learning; classroom management

\section{Introduction}

School research, teachers and institutions must have an interest in improving students' engagement and academic success. Teachers' supporting autonomy style and the basic psychological needs for autonomy, competence, and relatedness are major predictors for school engagement and academic success [1-3]. As a basis for this, firstly, stimulating learning environments are needed to foster students' active involvement and capacity to take responsibility for their learning. Secondly, strategies of classroom management are required that reduce teachers' role of being authoritarians but are still tailored to the demands of teaching.

\subsection{Bringing the Science Centre into Schools}

In contrast to everyday school life, "Scientific field trips to science centres can generate a sense of wonder, interest, enthusiasm, motivation, and eagerness to learn, which are much neglected in traditional formal school science" [4] (p. 125). Science centers often present fluid transitions between 
education and entertainment [5], providing opportunities for cognitive [6] as well as social and affective learning $[7,8]$. They offer authentic experiences with natural and technological phenomena combined with an autonomous, active and student-centred learning. This focus on a person's active involvement during a task should address students' engagement in a particular way [9]. Especially parameters such as intrinsic motivation, science learning achievement, interest in science and self-confidence can benefit from these learning experiences $[10,11]$.

Although advantages of out-of-school learning seem obvious, mainly monetary or logistic constraints (e.g., due to location, organization and implementation of scientific fieldtrips) often prevent field trips in daily school routine [11,12]. Efficient practical approaches for the implementation of scientific activities inside schools are still rare.

Bringing portable exhibits into schools could valuably complement out-of-school learning offers [4]. This "semi-formal" learning approach should be adapted simultaneously to teachers' and students' needs: Curriculum connection is one of the most often mentioned motivations for teachers to leave the classroom [13-15]. Used as a supplement to "normal" classroom instruction, portable exhibits provide opportunities to reinforce or expand the classroom curriculum [16]. Exhibits can easily be presented within a conceptual framework; they introduce a learning topic, summarize it, or deepen and extend it. Portable exhibits, put up in schools could link student-centred attributes with pre-determined learning objectives.

For the developed of exhibits and related tasks in alignment with school curricula and practical implementation schools, science centres and museums should cooperate to create a shared vision $[4,17]$. The integration of portable interactive augmented reality approaches into teaching have already shown positive effects on learning [18]. However, little literature considers the structure needed to support semi-formal learning environments [19] and the question remains which strategies could balance between teachers' control and students' autonomy.

\subsection{Structure and Autonomy Support}

\subsubsection{What Is the Right Degree of Structure?}

Degrees of structure usually are discussed controversially. In particular, the relationship between autonomy support and structure has been portrayed in different ways: from being antagonistic to curvilinear, and independent [20], whereas Cheon and colleagues found a positive correlation [21]. Teachers often prefer "structured student engagement" (e.g., docent-led guidance, worksheets or other writing activities) to free-choice learning [22,23]. Besides curricular specifications, the demand to keep students "on task" seems to be triggered by teachers' concerns about their ability to manage or control student behaviour, in particular within learning environments outside the classroom [11]. A feeling of not being able to maintain control is frequently cited as heightening teachers' stress [24,25].

In contrast, informal learning settings often provide unstructured and non-sequential learning environments [26,27]. Less structure, missing accountabilities and an oversupply of stimuli as well as information may hamper a student's focus on predetermined learning objectives [9] and intended connections, underlying the different types of exhibits $[9,28]$. Minimal guidance has been criticized regarding the achieved knowledge gain, see, e.g., [29-31]. A meta-analysis of Alfieri and colleagues clearly showed that directly guided instruction significantly improved knowledge gains in comparison to non-guided discovery learning settings [32]. Unlike rigid or unstructured formats, the more structured ones are often associated with an increase of feelings such as autonomy and achievement compared to either rigid or completely unstructured formats [33-36]. Different approaches seemingly minimize the amount of choice in favour of a combination of guidance and exploration [37-40]. Still, teacher-controlled guidance often reduces the opportunities to explore and is not always adjusted to the students' needs, in particular when taking intrinsic motivation and learning emotions into account $[41,42]$. 


\subsubsection{Intrinsic Motivation as a Predictor for Students' Engagement and Academic Success}

According to Self-Determination Theory (SDT), intrinsic motivation results from the perception that one's basic needs for autonomy, competence and relatedness are satisfied [43]. Needs for competence imply to interact effectively with one's environment, to have opportunities to express one's abilities and to experience skilfulness [43]. The need for relatedness is associated with a feeling of connectedness to others within a social context rather than being isolated from others [44]. Autonomy is defined as the need to be the origin of one's own behaviour and the experience of volition, choice, and self-regulation [43].

Students' basic needs satisfaction predicts students' school engagement for learning activities, see, e.g., [45-47]. As a multidimensional construct, school engagement represents the way in which students act, feel and think [48] and in which they participate. It involves a behavioural, cognitive and emotional dimension: Behavioural engagement includes the compliance with school rules, students' involvement and persistence in school-related activities [49]. Cognitive engagement includes the understanding and use of self-regulated learning strategies such as planning, monitoring and evaluating one's own progress [50] and the motivation to learn [33]. Emotional engagement includes the emotional quality of a person's active involvement; it refers to students' attitudes towards learning, classmates and teachers and their personal identification with school and schoolwork [51].

Melchor and colleagues [2] assumed a mediation model (Figure 1) that is based on the positive correlation between autonomy support, psychological needs satisfaction, school engagement and academic success. They confirmed this model in a survey with 2034 Angolan students and 2302 Dominican Republic students.

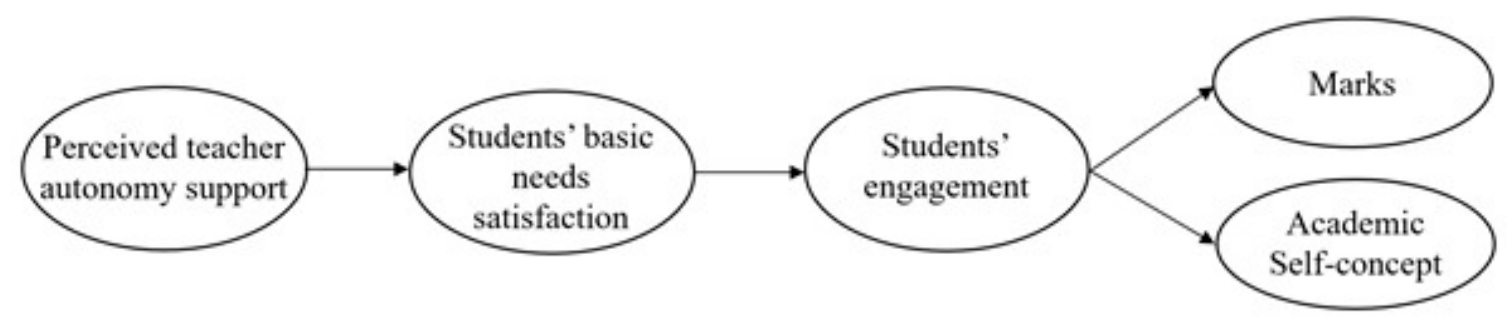

Figure 1. Predictors for cognitive outcomes and academic self-concept hypothesized by the mediation model [2].

In line with SDT, the mediation model stresses the importance of autonomy-supportive strategies to support students' engagement and academic success. Stimulating learning environments should clearly foster students' perception of having control over their learning process, but they should also meet school demands [20]. Peer-monitoring could be a promising approach to combine both, autonomy support and structure within group learning activities.

\subsection{Peer-versus Self-Monitoring to Regulate Students' Learning Behaviour}

As a student-centred learning approach, group learning is frequently used within formal and informal learning settings. Cooperative learning environments and learning settings in which one person (the tutor) imparts knowledge to another person (the tutee) combine cognitive activity with social interactions [52-55]. In comparison, instructional monitoring is typically based on behavioural activity, making it particularly suitable for classroom management. Hereby, self-monitoring is a self-management strategy that involves observing, assessing and regulating one's own behaviour [56]. It has been found to be a key process in self-regulated learning [57]. In contrast, reciprocal peer-monitoring implies monitoring classmates as well as being monitored. Brown and colleagues [58] defined peer-monitoring as peer-observing and checking the behaviour of others within the group regarding appropriateness and effectiveness. For both strategies of monitoring teachers as well as students could define target behaviours. Self-monitoring usually requires minimal training and is easy 
to implement [59], in contrast previous training for peer-monitoring depends on monitor variables (e.g., single vs. multiple behaviours) and the specific behaviour that is required. Interventions of self-monitoring, e.g., in [60-64] and peer-monitoring, e.g., in [58,63] have been applied to promote academic performance and "on-task" learning behaviours among students of different ages and across a variety of learning disabilities and emotional-behavioural difficulties. Thereby, self-monitoring was often used in learning settings with no possibilities for teacher control and in multiple contexts like math [65] and writing or reading performance [60].

Previous research can only be compared to a certain extent: Self-monitoring is mostly used in learning settings where students work on their own (e.g., while doing homework); whereas, peer-monitoring always implies social interactions. The scope of monitoring within and between both methods could differ from very little to intensive monitoring. In addition, monitoring could be used within different learning contexts and in combination with other instructional approaches, such as the use of a graphic organizer [60]. Thus, outcomes could differ fundamentally.

In the majority, both self- and peer-monitoring supported desired behaviours within the specific contexts and revealed to be equally effective, or superior to, teacher-directed procedures when knowledge gain was taken under consideration (see $[58,66]$ for peer-monitoring and $[67,68]$ for self-monitoring).

In contrast to positive effects of self-regulated learning on intrinsic motivation, self-efficacy and self-awareness [57], results of peer-monitoring are ambiguous. Henington and Skinner [67] stated that "peer monitoring can bring about both positive and negative social, emotional, and cognitive changes in students who are being monitored, as well as in those students doing the monitoring." (p. 251). Within the mediation model [2] autonomy support is an important predictor of students' intrinsic motivation. Peer-monitoring as "learners keeping an eye on whether their partners are going through appropriate and effective processes and procedures of learning" [58] (p. 174), could minimize students' perception of self-control in comparison to self-monitoring. Still, there is some evidence that regulation is not correlated with a feeling of restriction if guided by a person of the same age [46] and reciprocal peer-monitoring could establish a positive interdependence among students. Additionally, taking cooperative learning into account, peer-monitoring can strengthen prosocial behaviour [69]. In conclusion, so far, students' perception of peer-monitoring in comparison to self-monitoring is difficult to predict.

\subsection{Study Question}

To answer the research question if reciprocal and similar-age peer monitoring of students' activities should be recommended as guidance within semi-formal learning environments, we compared it with self-monitoring. Thus, we are among the first to test self- versus peer-monitoring with regard to effects on students' (1) cognitive achievement, (2) intrinsic motivation (perceived competence and perceived choice) and short-term learning emotions (anxiety, boredom, interest and well-being) as predictors of students' emotional engagement. Differences of previous literature in research designs, learning settings and the scope of monitoring prevents us from drawing concrete hypotheses, e.g., [63,70]. The comparison with self-monitoring could reveal important tendencies if peer-monitoring might be a key to guide group learning activities within semi-formal learning.

\section{Materials and Methods}

\subsection{Instructional Concept}

We designed a mobile exhibition to test for differences between peer- and self-monitoring. In line with an "Education for Sustainable Development" (ESD), our exhibits focused on the potential of renewable resources to replace fossil fuels, especially by focusing on bioenergy. As an interdisciplinary educational goal, ESD became part of the curriculum across all schools in most federal states within Germany. Content-wise, it addresses the Sustainable Development Goals (SDGs), defined as 
17 interlinked goals "to achieve a better and more sustainable future for all" [71]. As an essential part of the Agenda 2030 for Sustainable Development, the SDGs were set by the United Nations General Assembly in 2015 and are intended to be achieved by the year 2030. As part of young students' scientific literacy, it is not only imperative to sensitise their awareness of the finiteness of fossil fuels, but also to inform them about possible alternatives and related technologies. In contrast to wind, water and solar energy, educational approaches concerned with the topic of bioenergy are still limited and many students show only little knowledge of the use of biomass as an energy source [72,73]. This lack of knowledge seems to be independent of age and origin [74,75]. Within the exhibition, references can be made in particular to SDG 7, which proposes to "Ensure access to affordable, reliable, sustainable and modern energy for all" and to SDG 12, which calls to "Ensure sustainable consumption and production patterns".

Our exhibition offers eight mobile exhibits that focus on the heterogeneous nature of products based on renewable resources and used for bioenergy. They could be presented in out-of-school settings as well as inside schools. Exhibit modules can be used independently as solitary elements. We placed a special focus on the application of "hands-on" exhibits in combination with multi-sensory exploration as they are considered more attractive and leading to longer-lasting attention compared to non-participatory exhibits [76,77]. Exhibits 1-4 covered a comparison of products based on renewable resources and mineral-oil-based products by including four aspects:

1. sorting of different products based on their ingredients and the process of degradation;

2. using vision to compare natural and synthetic fibre structures with a microscope;

3. using touch in a haptic comparison of natural and synthetic fibre structures;

4. smelling and tasting of natural products used as food colorants and their assignment to associated products.

Exhibits 5-7 showed application forms of bioenergy based on renewable gaseous, solid and liquid biomass-based fuels; they included:

5. a miniature model of a biogas plant;

6. an "energy organ" consisting of eight columns (energy "content" of $1 \mathrm{~kW}$ each) filled with renewable and fossil fuels. Students compared volumes and energy values of renewable and fossil fuels;

7. the production of sunflower oil with a manual seed press, including its tasting and burning (conducted under supervision).

Exhibits 8 presented an interactive computer game as a voluntary learning activity that was not included in the knowledge questionnaire. The "energy race" required physical effort (displayed as $\mathrm{kW}$ ) by riding a fixed bicycle on a roll.

\subsection{Workbook Guidance}

In favour of one independent variable, we combined both peer- and self-monitoring with an instructional workbook, providing learners with guidance about how to interact with the exhibits—cf. [78] (p. 162 ff.). Following Krombaß and Harms [79], the workbook consisted of a closed task setting and was subdivided into sections; each section corresponded to a "hands-on" exhibit. The informational sheets provided clearly defined solutions and were, together with the workbook contents, subsequently monitored in the knowledge questionnaire. We focused on factual information in favour of a between-groups comparison with only one independent variable (peer- versus self-monitoring). Thus, we deliberately avoided open-ended tasks-cf. [4], in favour of group comparisons. 


\subsection{Implementation}

Within the framework of "Bringing the science centre to school" the mobile exhibition was offered to secondary schools (Level 2 of the International Standard Classification of Education) in Bayreuth (Bavaria) and the surrounding area. The data were collected by carrying out a questionnaire survey with a pre-, post- and retention-test design, including a control.

In total, 470 students (8th/9th grade) participated, with an average age of 14 years (8th) and 15 years (9th grade). Classes from different schools were randomly assigned to the experimental groups, but students from the 8th and 9th grades were not mixed.

The visit of the exhibition was part of an educational programme: Two groups, a self-monitored group ( $n=218$, female: $47.7 \%)$ and a peer-monitored group $(n=230$, female: $49.4 \%)$ participated in our preliminary session (20 $\mathrm{min})$, the workbook-guided visit $(90 \mathrm{~min}$ ) of the exhibition and the debriefing session (15 $\mathrm{min}$ ) (see Figure 2). An additional control group ( $n=22$, female: $34.8 \%$ ) did not participate in the educational programme. The preliminary session of the programme was divided in two parts: The first part comprised a topical introduction that provided background knowledge for a more profitable learning experience. The second included an introduction to the process of monitoring (see Section 2.4). The debriefing session (15 min) summarized the learning outcomes. The same person conducted the preliminary and the debriefing sessions to avoid any "teacher effects" within test results; during the workbook-guided visit of the exhibition, there was no teacher guidance. Per day, two classes visited the exhibition with a time frame of $135 \mathrm{~min}$ per class. The number of students in the exhibition did not exceed 34 at any given moment. Classes were randomly divided into self- and peer-monitored groups and subdivided, also randomly, into groups with up to four students each. Both treatment groups completed identical exhibit-related and workbook-guided activities. We specified different rotation sequences for each group in the workbook to provide a smooth cycle between exhibits. Each group had a time frame of up to $15 \mathrm{~min}$ per exhibit.

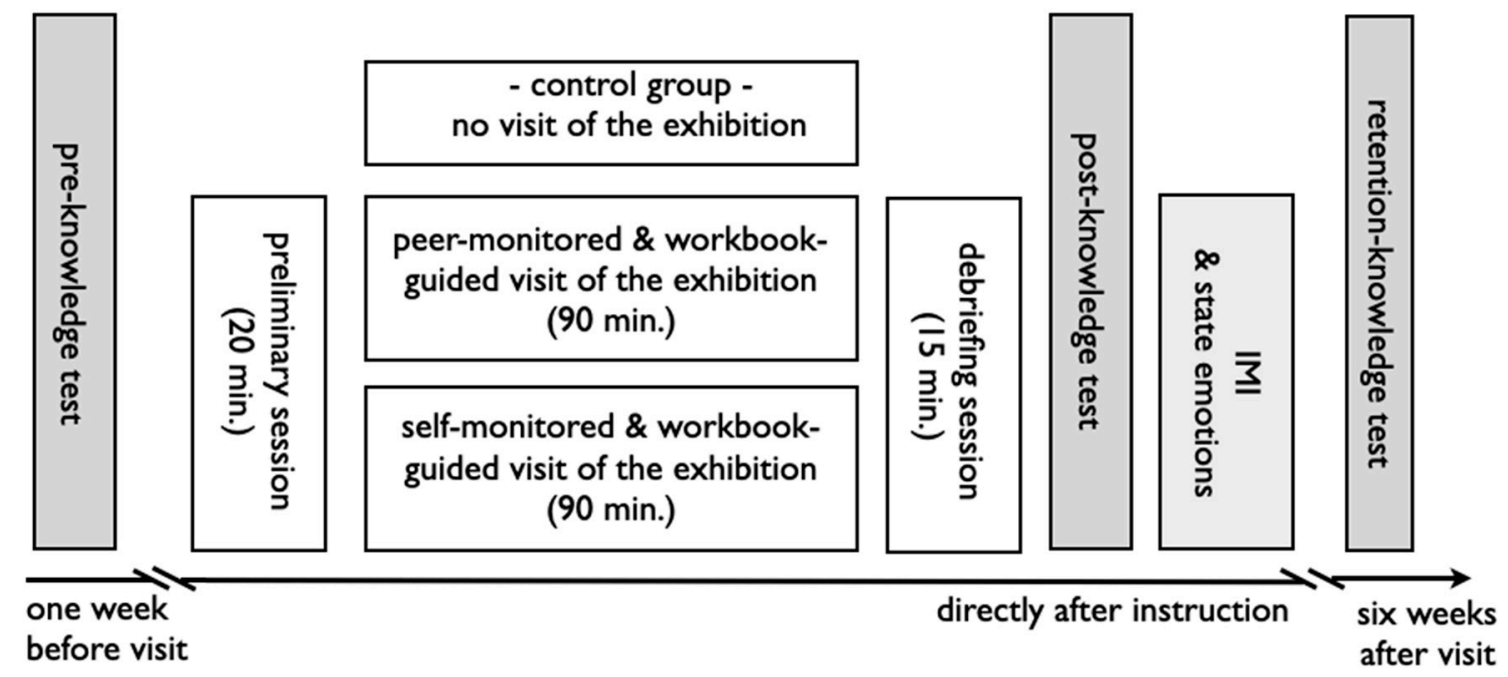

Figure 2. Overview of the study design including the two interventions and the control group (white boxes), applied scales (grey boxes) and time of testing indicated by an arrow.

\subsection{Self-versus Peer-Monitoring}

The experimental groups differed in internal regulation (self-regulated behaviour) and externally regulated behaviour (peer-regulated behaviour). We defined particular target behaviours that should help students to keep the focus on specific learning objectives-see [66], which were communicated to both groups. The self-monitored group assessed individual learning behaviour by checkmarks that were placed on supplementary sheets. In addition, behavioural rules were fixed on a poster that was put up in front of the class (self-monitored group) or connected with specific roles and written down 
on role cards (peer-monitored group). Each peer-monitored group received a little bag with the same amount of role cards as group members. Before starting with an exhibit, each person had to draw a card out of the bag and put it back when finished. Meanwhile, role card holders were responsible for the adherence of role instructions (Table 1) by the rest of the group. Requisites visualized specific roles; e.g., glasses for the role as a reader.

Table 1. Description of role-specific instructions as target behaviours for peer-monitoring.

\begin{tabular}{|c|c|c|c|}
\hline $\begin{array}{l}\text { Reader Read out to the } \\
\text { Rest of the Group ... }\end{array}$ & $\begin{array}{c}\text { Moderator Monitored } \\
\text { That Peers ... }\end{array}$ & $\begin{array}{c}\text { Material Guard } \\
\text { Monitored That } \\
\text { Peers ... }\end{array}$ & $\begin{array}{c}\text { Inspector Monitored } \\
\text { That Peers ... }\end{array}$ \\
\hline $\begin{array}{l}\text { short operating } \\
\text { procedures at } \\
\text { each exhibit. }\end{array}$ & $\begin{array}{l}\text { stayed focused on } \\
\text { the topic. }\end{array}$ & $\begin{array}{l}\text { handled materials } \\
\text { with care. }\end{array}$ & $\begin{array}{l}\text { tried to solve all exhibit } \\
\text { related activities. }\end{array}$ \\
\hline \multirow[t]{2}{*}{$\begin{array}{l}\text { information written } \\
\text { down in the workbook. }\end{array}$} & $\begin{array}{l}\text { did not disturb other } \\
\text { groups and worked } \\
\text { quietly (measured by a } \\
\text { sound level meter). }\end{array}$ & $\begin{array}{l}\text { left each exhibit tidy } \\
\text { and neat. }\end{array}$ & $\begin{array}{l}\text { recorded all results in } \\
\text { the workbook. }\end{array}$ \\
\hline & $\begin{array}{l}\text { finished each } \\
\text { exhibit-related task that } \\
\text { had been started. }\end{array}$ & & $\begin{array}{l}\text { finished activities before } \\
\text { the comparison of own } \\
\text { results with provided } \\
\text { solutions. }\end{array}$ \\
\hline
\end{tabular}

\subsubsection{Measurement of Science Learning Outcomes}

We applied a pre-, post- and retention test to monitor pre-knowledge as well as the short- and long-term learning effects of the self- and peer-monitored groups. For the assessment of knowledge achievement (as the dependent variable), we developed a multiple-choice questionnaire with 21 items and four distractors per item. A pilot study validated the multiple-choice questionnaire on the basis of 25 students (female: $45.8 \%$ ) without visiting the exhibition. Questions covered factual knowledge with regard to workbook tasks and information sheets (see Table 2).

Table 2. Listing of four item examples of the science achievement questionnaire ${ }^{1}$.

\begin{tabular}{|c|c|c|c|}
\hline $\begin{array}{l}\text { 1. Which Plant Is } \\
\text { Used for Liquid } \\
\text { Fuel Production in } \\
\text { Germany? }\end{array}$ & $\begin{array}{l}\text { 2. Which Source of } \\
\text { Energy Is Based on } \\
\text { Mineral Oil? }\end{array}$ & $\begin{array}{l}\text { 3. The Origin of } \\
\text { Bioenergy Is Based on } \\
\ldots\end{array}$ & $\begin{array}{l}\text { 4. Mineral Oil Arises } \\
\text { from ... }\end{array}$ \\
\hline (a) barley & (a) gasoline & (a) wind & \multirow{4}{*}{$\begin{array}{l}\text { (a) dinosaur fossils } \\
\text { (b) underground } \\
\text { methane bubbles } \\
\text { (c) emissions of black } \\
\text { smokers in the deep sea } \\
\text { (d) dead marine } \\
\text { organisms }\end{array}$} \\
\hline (b) rye & (b) heating oil & (b) sunlight & \\
\hline (c) wheat & (c) biodiesel & (c) water & \\
\hline (d) rape & (d) plastic & (d) geothermal energy & \\
\hline
\end{tabular}

${ }^{1}$ Note that more than one correct answer could be given.

We used the same questions and students' incorrect answers as distractors in the multiple-choice questionnaire and conducted a distractor analysis $(n=51$, female: $36.2 \%$; note that gender distribution was not balanced). Based on this analysis, we selected distractors with a solution probability that varied from $20 \%$ to $80 \%$. We applied an item difficulty index of about $25 \%$ easy items, $50 \%$ medium items and $25 \%$ difficult items [80]. Multiple-choice items had a sufficient level of internal consistency, determined by Cronbach's alpha coefficients $(n=470)$ of 0.651 (pre-knowledge), 0.751 (post-knowledge) and 0.688 (retention-knowledge) [81]. In the main study, students completed the pre-test one week before participation, the post-test immediately after, and the retention test six to eight weeks later (Figure 1). Students were not informed about the test schedules or repeated applications; see, e.g., [82]. 
Additionally, students were assured that their responses would have no influence on their school marks. We advised teachers not to make any thematic connection to the exhibition until finishing the study with the retention questionnaire. In order to exclude external learning variables not due to the programme-e.g., [83], a control group ( $n=22$, female: $34.8 \%)$ completed the questionnaire three times without participating in the programme. In the statistical analysis, we considered gender differences because the distribution was not balanced.

\subsubsection{Measurement of Predictors for Short-Term Learning Emotions and Intrinsic Motivation}

Within the post-questionnaire, we assessed students' short-term learning emotions and indicators for students' intrinsic motivation as dependent variables. The German translation [84] of the subscales-perceived competence ( 6 items, e.g., "I was pretty skilled at this activity.") and perceived choice (7 items, e.g., "I did this activity because I wanted to.")—of the intrinsic motivation inventory [85] was applied as well as subscales for the short-term learning emotions (4 items each, which also included reversed items) of anxiety (e.g., "I felt under pressure during the activity."), boredom (e.g., "I felt bored."), interest (e.g., "I want to learn more about that topic.") and well-being (e.g., "I enjoyed the activity"); based on Gläser-Zikuda and colleagues [86] and adapted by Meissner and Bogner [87]. Both instruments used a 4-point Likert scale ( $1=$ very high, $4=$ very low). We assessed sufficient Cronbach's alpha coefficients between 0.730 and 0.849 for all scales [81].

\subsection{Statistics}

SPSS Statistics was used for data analysis. The effect size $(r=z \sqrt{ } N)$ was calculated according to Field [88] with 0.10 regarded as a small, 0.30 as a medium, and 0.50 as a large effect size [89]. We conducted a non-parametric Mann-Whitney test for inter-group differences and a Wilcoxon signed-rank test for within group differences, due to the non-normal distribution of our scores (Kolmogorov-Smirnov test, $p<0.05$ ). Additionally, a binary logistic regression measured the relationship between the post- or retention knowledge (categorical dependent variable) and scenario, pre-knowledge and gender (independent predictor variables). Results display the odds ratio as a probability score where the independent variable is a predictor of the dependent variable. We included the effect of pre-existing knowledge, gender and the interaction as predictor variables. The odds ratio shows the effect of the variables in the equation (reference category: peer-monitored group, right answer, male); odds ratio $=1$ reflects no difference in knowledge gain, odds ratio $>1$ indicates a higher, and odds ratio $<1$-a lower probability to give correct answers.

\section{Results}

For none of the group comparisons significant differences were calculated for different grades or gender.

\subsection{Within-Group Comparison of the Control Group}

A control group $(n=22)$ completed our questionnaires at the three test intervals. A comparison between pre-test $(25$ th/75th, $\mathrm{P}=6.0 / 11.25$, median $=10)$, post-test $(25$ th $/ 75$ th, $\mathrm{P}=8.75 / 12$, median $=10)$ and retention test $(25$ th/75th, $\mathrm{P}=6 / 13$, median $=10)$ revealed neither external short- and long-term nor persistent learning effects: Pre- versus post-test $(\mathrm{z}=-1.28, p=0.2, \mathrm{r}=0.27)$; pre- versus retention test $(\mathrm{z}=-0.68, p=0.50, \mathrm{r}=0.15)$; post-test versus retention test $(\mathrm{z}=-0.49, p=0.63, \mathrm{r}=0.10)$.

\subsection{Science Learning Outcome}

Sum scores of correct answers of both peer- and self-monitoring showed a highly significant knowledge increase in short- and long-term learning outcomes in comparison to pre-knowledge. Long-term achievement decreased in both groups in comparison to short-term learning outcomes (Figure 3). 


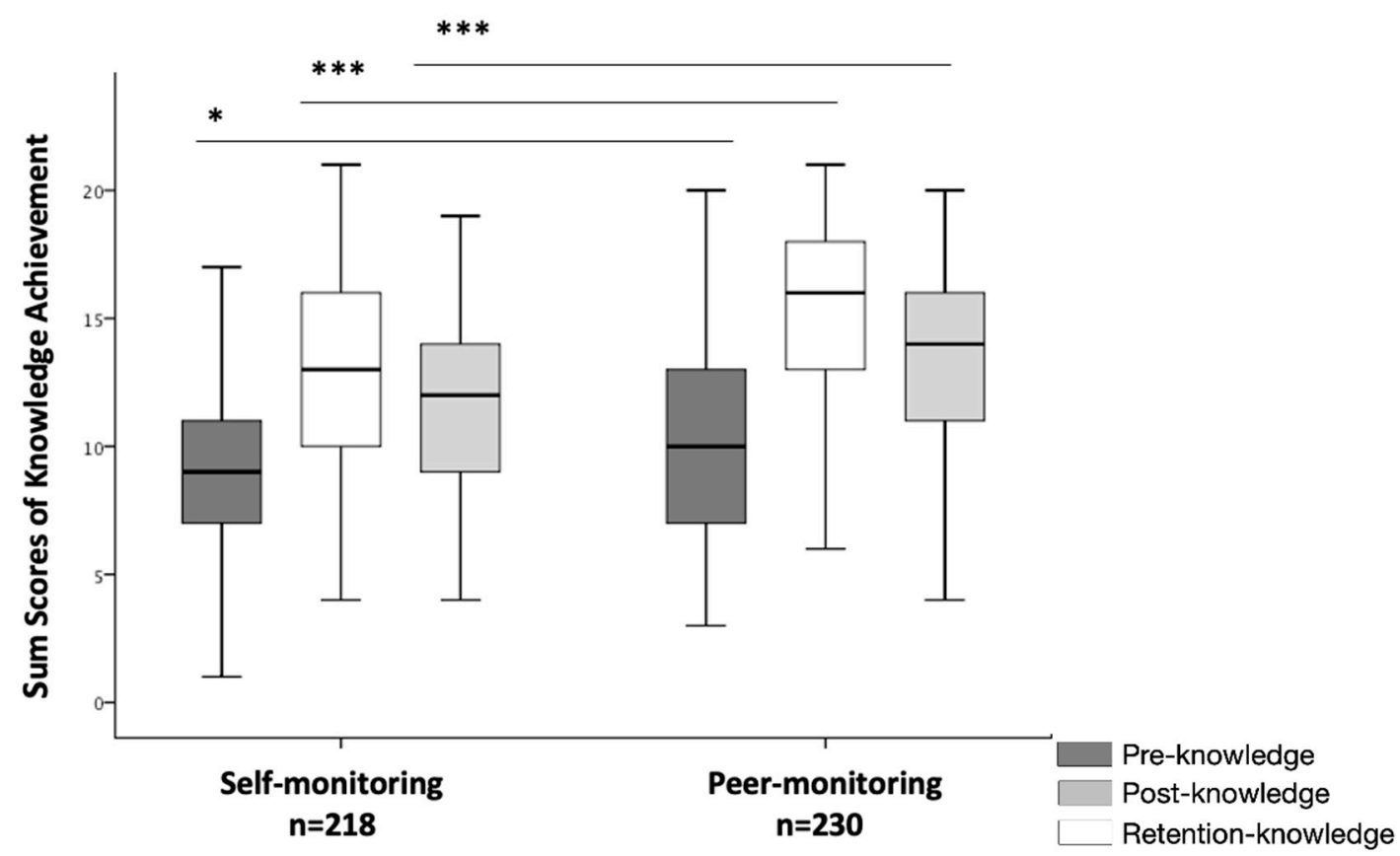

Figure 3. Box-and-whisker plot showing sum scores of knowledge achievement of the self- and peer-monitored group at the three times of testing. Note: The box-and-whisker plot indicates the median, lower and upper quartile and the 9 th and 91st percentile; ${ }^{* * *}$ significant at $<0.001,{ }^{*}$ significant at $<0.05$.

\subsection{Peer-versus Self-Monitoring}

At all testing times, the peer-monitored group showed higher achievement outcomes (pre-, postand retention test) than the self-monitored group (Table 3). Differences remained if effects of the predictor variables of pre-knowledge and gender were excluded. In detail: Our inter-group comparison of science knowledge achievement scores (21 items) showed that, immediately after the programme, the peer-monitored cohort $(25 \mathrm{th} / 75 \mathrm{th}, \mathrm{P}=13.0 / 18.0$, median $=16)$ performed significantly better than the self-monitored cohort (25th/75th, $P=10.0 / 16.25$, median $=13),(U=17837.50, z=-5.30, p<0.001 * * *$, $r=0.25)$. The better performance of the peer-monitored group (25th/75th, $P=10.0 / 16.0$, median $=14$ ) compared to the self-monitored group $(25 \mathrm{th} / 75 \mathrm{th}, \mathrm{P}=9.0 / 14.0$, median $=12)$ still persisted six weeks after the programme $\left(\mathrm{U}=18872, \mathrm{z}=-4.54, p<0.001^{* * *}, \mathrm{r}=0.21\right)$. A higher score of the peer-monitored cohort $(25$ th/75th, $\mathrm{P}=7.0 / 13.0$, median $=10)$ was already visible in the pre-knowledge test $(\mathrm{U}=21835$, $\left.\mathrm{z}=-2.37, p<0.018^{*}, \mathrm{r}=0.11\right)$ in comparison to the self-monitored cohort $(25 \mathrm{th} / 75 \mathrm{th}, \mathrm{P}=7.0 / 11.0$, median $=9$ ).

Table 3. Group comparison of science knowledge achievement between different times of testing.

\begin{tabular}{ccccccc}
\hline & \multicolumn{2}{c}{ Self-Monitored Group $(n=\mathbf{2 1 8})$} & \multicolumn{2}{c}{ Peer-Monitored Group $(n=230)$} \\
\cline { 2 - 6 } & T1 & T2 & T3 & T1 & T2 & T3 \\
\hline 25th/75th P & $7.0 / 11.0$ & $10.0 / 16.25$ & $9.0 / 14.0$ & $7.0 / 13.0$ & $13.0 / 18.0$ & $10.8 / 16.0$ \\
Median & 9.0 & 13.0 & 12.0 & 10.0 & 16.0 & 14.0 \\
& T1:T2 & T1:T3 & T2:T3 & T1:T2 & T1:T3 & T2:T3 \\
z & -11.52 & -8.84 & -6.20 & -12.31 & -10.62 & -9.56 \\
$p$ & $<0.001^{* * *}$ & $<0.001^{* * *}$ & $<0.001^{* * *}$ & $<0.001 * * *$ & $<0.001^{* * *}$ & $<0.001^{* * *}$ \\
r & -0.78 & -0.60 & -0.42 & -0.81 & -0.70 & -0.63 \\
\hline
\end{tabular}

Note: Wilcoxon signed-rank test $\mathrm{z} ;{ }^{* * *}$ significant at $p<0.001$, exact one-tailed significance; effect size $\mathrm{r}$. 
We applied a logistic regression to test for the influence of pre-existing knowledge and gender in post- (Table 4) and retention knowledge (Table 5). Asterisks indicate that all predictor variables (scenario, pre-knowledge and gender) for post- as well as for retention knowledge were statistically significant (with the exception of gender in step 5 for the retention knowledge): Depending on the predictor included in the model, the odds ratio reveals a probability, which is $33.1 \%$ (odds ratio $=0.669$ ) to $39.8 \%$ (odds ratio $=0.602$ ) higher, that the self-monitored group responds incorrectly in the post-knowledge test (Table 4). The retention knowledge test shows similar results, with a probability that is $22.3 \%$ (odds ratio $=0.777)$ to $40.8 \%$ (odds ratio $=0.592)$ higher $($ Table 4$)$.

Table 4. Logistic regression predicting "post-knowledge" from scenario, pre-knowledge and gender by odds ratio.

\begin{tabular}{|c|c|c|c|c|c|c|}
\hline Variable & Reference & Step 1 & Step 2 & Step 3 & Step 4 & Step 5 \\
\hline Intervention & peer-mediated & $0.669 * *$ & $0.687^{* *}$ & $0.602 * *$ & $0.605^{* *}$ & $0.691 * *$ \\
\hline Pre-knowledge & right answer & & $0.387^{* *}$ & $0.347^{* *}$ & $0.353^{* *}$ & $0.350 * *$ \\
\hline Intervention $\times$ Pre-knowledge & & & & $1.230 *$ & $1.222 *$ & $1.238 *$ \\
\hline Gender & male & & & & $0.798^{* *}$ & 916 \\
\hline Intervention $\times$ Gender & & & & & & $0.769^{* *}$ \\
\hline Constant & & $2.483 * *$ & $4.296 * *$ & $4.601 * *$ & $5.126^{* *}$ & $4.795^{* *}$ \\
\hline
\end{tabular}

Table 5. Logistic regression predicting "retention-knowledge" from scenario, pre-knowledge and gender by odds ratio.

\begin{tabular}{|c|c|c|c|c|c|c|}
\hline Variable & Reference & Step 1 & Step 2 & Step 3 & Step 4 & Step 5 \\
\hline Intervention & peer-mediated & $0.752 * *$ & $0.777^{* *}$ & $0.592 * *$ & $0.593^{* *}$ & $0.601 * *$ \\
\hline Pre-knowledge & right answer & & $0.353 * *$ & $0.281^{* *}$ & $0.284^{* *}$ & $0.283^{* *}$ \\
\hline Intervention $\times$ Pre-knowledge & & & & $1.572 * *$ & $1.567^{*}$ & $1.569^{* *}$ \\
\hline Gender & male & & & & $0.890^{* *}$ & 902 \\
\hline Intervention $\times$ Gender & & & & & & 974 \\
\hline Constant & & $1.622 * *$ & $2.901 * *$ & $3.326^{* *}$ & $3.513^{* *}$ & $3.490 * *$ \\
\hline
\end{tabular}

\subsection{Short-Term Learning Emotions and Intrinsic Motivation}

Students of the peer-monitored group had a significantly lower perception of their level of boredom and anxiety and a significantly higher perception of their level of competence in comparison to the self-monitored group (Table 6). We did not record any differences with regard to the perception of choice, well-being and interest. Within all between-group comparisons, the effect size $r$ was small.

Table 6. Between-group comparison of predictors for the perception of short-term learning emotions (left side) and intrinsic motivation (right side).

\begin{tabular}{cccccccc}
\hline Variable & & Well-Being & Interest & Boredom & Anxiety & Competence & Choice \\
\hline $\begin{array}{c}\text { Self-monitored } \\
(n=152)\end{array}$ & $(25$ th/75th $\mathrm{P})$ & $1.3 / 2.3$ & $1.5 / 2.5$ & $2.8 / 3.5$ & $3.3 / 3.5$ & $2 / 2.5$ & $1.6 / 2.6$ \\
\cline { 2 - 8 } & Median & 1.8 & 2 & 3 & 3.5 & 2.3 & 2.1 \\
\hline Peer-monitored & $(25$ th/75th P $)$ & $1.5 / 2.3$ & $1.5 / 2.5$ & $2.8 / 3.8$ & $3.3 / 4$ & $1.8 / 2.5$ & $1.6 / 2.3$ \\
\cline { 2 - 7 }$(n=230)$ & Median & 1.9 & 2 & 3.3 & 3.8 & 2.2 & 2 \\
\hline & $\mathrm{U}$ & 17254 & 17256 & 15298 & 14810 & 14377 & 16324 \\
Between-group & $\mathrm{z}$ & -0.22 & -0.22 & -2.08 & -2.59 & -2.96 & -1.1 \\
comparison & $p$ & 0.83 & 0.83 & $0.04^{*}$ & $0.01^{* *}$ & $0.003^{* *}$ & .27 \\
& $\mathrm{r}$ & 0.01 & 0.01 & 0.11 & 0.13 & 0.15 & 0.06 \\
\hline
\end{tabular}

Note: Mann-Whitney $\mathrm{U}$ test and $\mathrm{z} ;{ }^{* *}$ significant at $p<0.01,{ }^{*}$ significant at $p<0.05$, exact one-tailed significance; effect size $r$. 


\section{Discussion}

Based on the mediation model (see Figure 1), we assumed that peer-monitoring should support students' capacity to take control of their learning, if monitoring is not connected with a feeling of restriction. We proposed peer-monitoring of students' activities as an instructional guidance within semi-formal learning environments. In comparison to previous studies that had a strong focus on academic achievement, the study at hand examined not only students' learning outcomes, but also affective predictors for students' classroom engagement. The between-group comparison underlined that the application of peer-monitoring resulted in an increased level of knowledge combined with a better perception of competence, while anxiety and boredom levels diminished.

In favour of comparability, cognitive and affective effects are considered separately, even though engagement is a multifaceted construct and cognitive learning outcomes, intrinsic motivation and short-term learning emotions should not be regarded as isolated factors but as influencing each other; see $[90,91]$.

\subsection{Within-Group Comparison}

Both the self- and the peer-monitored group demonstrated a significant increase in short- and long-term cognitive learning. This is in line with previous research in peer-monitoring $[58,66]$ and self-monitoring $[67,68]$ that focused on students' knowledge gain.

We did not compare workbook with non-workbook guidance, but we still can conclude that the applied workbooks provided guidance about how to interact with the exhibit and seemed to be effective with regard to factual knowledge. Our results support the combination of instructions for behavioural activity with an additional assistance to structure cognitive activity, such as workbooks. They are in accordance with Kromba $\beta$ and Harms [79], who showed positive effects of worksheets for acquiring basic knowledge in a natural history museum. Researchers provide counterarguments like the restriction of exploration [92,93] and pro-arguments, e.g., facilitating group dialogues and curriculum connection [94] with regard to worksheets in an out-of-school learning setting. In accordance with Kisiel $[14,23]$ we emphasize that not simply the presence or absence, but the realisation of well thought-out workbooks or -sheets matters. Especially workbooks that are in line with inquiry- and problem-based learning could be very engaging.

To conclude this point, well-designed workbooks that fit curriculum standards and the learning objectives intended by the design of exhibits can help to bring more scientific activities into the classroom and create a shared vision between schools, science centres and museums; see $[4,94]$ (p. 1389).

\subsection{Between-Group Comparison (Peer- versus Self-Monitoring)}

\subsubsection{Science Learning Outcomes}

The peer-monitored instruction revealed better short- and long-term learning outcomes compared to the self-monitored group. Efficiency of peer-monitoring has been shown especially with regard to its function of keeping learners on track $[58,66]$. McCurdy and Shapiro revealed teacher- and peer-monitoring of process learning behaviours to be equally effective [95]. It seems likely that a higher percentage of "on-task" behaviour is also connected with better learning outcomes. Likewise, self-monitoring could increase "on-task" behaviours, particularly when incorporated with other instructional approaches [60]. The assessment of one's own learning behaviour requires self-regulation. However, this should be expected from the studies' participants who attended secondary school with an age range of 13 to 16 years. Particularly young children or student populations with high incidence of disabilities or learning difficulties face challenges in self-regulation during independent learning $[95,96]$.

As an additional explanation, the distribution of tasks between learners within peer-monitored groups could have a positive effect on learning outcomes. King [97] introduced the idea of distributed 
metacognition by the distribution of components of control among collaborating learners (p. 61, $70 \mathrm{f}$.). Although we did not perform an observational study, we detected interesting group dynamics within the self-monitored group: Some students took over a "leader function", while others became passive followers. Scharfenberg and colleagues showed in a video analysis that even in hands-on lessons, passive followers remain passive [98]. In the peer-monitored group, activity cards challenged all participants to accept responsibility for a specific task, engaging thus both active and passive students, as well as low and high achievers.

\subsubsection{Predictors for Students' Emotional Engagement}

Neither effect sizes of short-term learning emotions nor predictors for intrinsic motivation revealed high values (Table 3). Thus, significant differences between results should not be overestimated.

\section{Students' Intrinsic Motivation}

In comparison to self-monitoring, peer-monitoring resulted in a higher perception of competence and choice, both subscales are indicators for intrinsic motivation; e.g., [45,99].

Peer-assisted learning promotes competence and autonomy among students, which has a positive effect on students' self-conceptions; for a review, see [100,101]. However, peer-monitoring considered as peer-controlled learning behaviour should not be equated with peer-assistance. A higher perception of competence and choice in peer-monitoring, compared to self-monitoring, is an interesting result.

The assignation and performance of specific roles might be connected with the higher perception of competence. A feeling of competence implies to interact effectively with one's environment and to have opportunities to express one's abilities and to experience skilfulness. Reciprocal and same-age peer-monitoring could establish a positive interdependence among students that might trigger these characteristics. Within Self-Determination Theory, the three "psychological needs" of competence, relatedness and autonomy interact with each other; see, e.g., [45,47]. In favour of having a reasonable number of questionnaire items, we did not measure social relatedness, although collaboration and cooperation are seen as critical in learning and engagement [102]. Social relatedness is an important factor, in particular with regard to informal learning settings and might play an important role especially for young people $[103,104]$. Working in small groups in combination with the application of roles could have influenced group dynamics and social relatedness positively —cf. [105].

When coming back to our initial question, the lack of significant differences in the perception of control is a promising result. It indicates that in comparison to self-monitoring, peer-monitoring might not be perceived as an external control of behaviour. Finally, intrinsic motivation is a multifaceted construct and we cannot explain all interactions between the psychological needs, but we can still conclude that peer-monitoring seems to shape a social environment, which fosters single predictors for intrinsic motivation.

\section{Short-Term Learning Emotions}

Self- and peer-monitored instruction did not provoke notable effects on well-being and interest, but peer-monitoring lowered the perceived level of anxiety and boredom. Short-term learning emotions cannot always be expected to be long-lasting, but they can very much influence learning processes [106-108]. Anxiety and boredom are defined as specific "achievement emotions" which correspond to students' learning achievements [91].

The application of roles that specified particular target behaviours may also explain why students felt less bored: Role keepers had to make sure that the rest of the group followed instructions connected with their specific role; additionally, their behaviour was monitored by group members. It is likely that both actions kept students more active than those in the self-monitored group.

Interestingly, Pekrun and colleagues [109] stated: "Self-regulating one's own learning may induce positive feelings, whereas external control may induce anger, anxiety, or boredom" (p. 99). In 2010, they confirmed the inverse relation of boredom with self-regulation [110]. 
In view of this, peer-monitoring in combination with the performance of specific roles did not seem to be perceived as an external control and a loss of self-regulation. This may be due to the fact that peers are not perceived as an authority; each person in the group performs a specific task that could be experienced as part of a game, as "without rules there is no game" [111]. We tried to avoid the risks of comparisons within the groups, the "competence threat" and social divisiveness [112] by applying a structured switching of roles. Interestingly, Ryan, Stiller and Lynch [113] described pupils as internalizing extrinsic school regulations when they felt secure and cared for. The reduced perception of anxiety is an intriguing phenomenon; Gläser-Zikuda and colleagues [86] described self-regulated learning as requiring a variety of strategies that need to be performed before they may be experienced as emotionally positive and valuable. Although both groups were expected to follow similar behavioural rules, the higher perception of anxiety within the self-monitored group could be based on insufficient experience in self-regulated learning, creating insecurity. In different contexts, the new and unknown may have overwhelmed students and influenced the cognitive [114] as well as the affective outcomes [115] negatively. With the application of role cards, students knew and told each other how to behave, apparently being emotionally reassuring, and thereby reducing the level of perceived anxiety [116].

\section{Conclusions}

In accordance to Malcolm, Hodkinson and Colley [117] we conceive "formality" and "informality" as attributes present in all circumstances of learning that should not be considered separately. We are amongst the first to suggest peer-monitoring conducted with the performance of specific roles in combination with workbook guidance to better link these attributes. The application of role cards provides an easy and cost-efficient implementation to define and target specific learning behaviours. Hence, peer-monitoring is not an informal support but refers to a learning situation planned by a professional teacher and the amount of structure ought to be adapted to requirements, purpose and context individually. In conclusion, peer-monitoring in combination with well-designed workbooks seems a fruitful approach that implies reduced teacher control but is still tailored to teachers' needs. This could provide an enriching repertoire of student-centred learning opportunities, suitable not only in out-of-school contexts, but also during classroom teaching. Our research contributes to the fields of "semi-formal learning" as well as motivation and autonomy in group learning.

\section{Limitations and Recommendations}

Behind the background that autonomy support is a determining factor to improve students' engagement and academic success, a limitation of this study was that the educational environment provided limited possibilities for students to be creative. In favour of a between-group comparison, we deliberately avoided open-ended tasks and had a focus on factual information. Learning tasks could have been presented in a much more stimulating way, especially when taking inquiry-based learning and problem solving into account. This also points out a research challenge: self-control individualises learning processes and makes it difficult to compare the efficiency of different methodologies. In a broader context politicians, economists and scientists should discuss approaches that bridge the gap between curricular demands, social structures characterised by comparability and students' individual needs for autonomy.

Author Contributions: Funding acquisition, F.X.B.; Supervision, F.X.B.; Writing—original draft, Y.C.L.; Writing-review \& editing, J.G., F.X.B. and Y.C.L. All authors have read and agreed to the published version of the manuscript.

Funding: Funding was provided by the University of Bayreuth and the Bioenergy-Region Bayreuth. Additionally, the German Research Foundation (DFG) in the funding program Open Access Publishing under grant agreement no. LA 2159/8-6. funded this publication. The funders had no role in the design of the study, in the collection, analyses, or interpretation of data, in the writing of the manuscript, or in the decision to publish the results. This article reflects only the authors' views. The funders are not liable for any use that might be made of the information contained herein. 
Acknowledgments: We are very thankful to all students for participating and we greatly appreciate the support of the Bioenergy-Region Bayreuth represented by B. Rothammel.

Conflicts of Interest: The authors declare no conflict of interest.

\section{References}

1. Raufelder, D.; Kittler, F.; Braun, S.R.; Lätsch, A.; Wilkinson, R.P.; Hoferichter, F. The interplay of perceived stress, self-determination and school engagement in adolescence. Sch. Psychol. Int. 2014, 35, 405-420. [CrossRef]

2. Gutiérrez, M.; Sancho, P.; Galiana, L.; Tomás, J.M. Autonomy support, psychological needs satisfaction, school engagement and academic success: A mediation model. Univ. Psychol. 2018, 17, 1-12. [CrossRef]

3. Jang, H.; Kim, E.J.; Reeve, J. Longitudinal test of self-determination theory's motivation mediation model in a naturally occurring classroom context. J. Educ. Psychol. 2012, 104, 1175-1188. [CrossRef]

4. Eshach, H. Bridging in-school and out-of-school learning: Formal, non-formal, and informal education. J. Sci. Educ. Technol. 2007, 16, 171-190. [CrossRef]

5. Schwan, S.; Grajal, A.; Lewalter, D. Understanding and Engagement in Places of Science Experience: Science Museums, Science Centers, Zoos, and Aquariums. Educ. Psychol. 2014, 49, 70-85. [CrossRef]

6. Lelliott, A. Understanding Gravity: The Role of a School Visit to a Science Centre. Int. J. Sci. Educ. Part B Commun. Public Engagem. 2014, 4, 30-322. [CrossRef]

7. Şentürk, E.; Özdemir, Ö.F. The Effect of Science Centres on Students' Attitudes Towards Science. Int. J. Sci. Educ. Part B Commun. Public Engagem. 2014, 4, 1-24. [CrossRef]

8. Falk, J.H.; Needham, M.; Dierking, L.; Prendergast, L. International Science Centre Impact Study Final Report; University Press: Corvallis, OR, USA, 2014; p. 45.

9. Allen, S. Designs for learning: Studying science museum exhibits that do more than entertain. Sci. Educ. 2004, 88, S17-S33. [CrossRef]

10. DeWitt, J.; Storksdieck, M. A short review of school field trips: Key findings from the past and implications for the future. Visit. Stud. 2008, 11, 181-197. [CrossRef]

11. Anderson, D.; Kisiel, J.; Storksdieck, M. Understanding Teachers' Perspectives on Field Trips: Discovering Common Ground in Three Countries. Curator Museum J. 2006, 49, 365-386. [CrossRef]

12. Falk, J.H.; Dierking, L. Lessons without Limit: How Free-Choice Learning Is Transforming Education; AltaMira Press: Walnut Creek, CA, USA, 2002.

13. Anderson, D.; Zhang, Z. Teacher Perceptions of Field-Trip Planning and Implementation. Visit. Stud. Today 2003, VI, 6-11.

14. Kisiel, J.F. Teachers, Museums and Worksheets: A Closer Look at a Learning Experience. J. Sci. Teacher Educ. 2003, 14, 3-21. [CrossRef]

15. Kisiel, J. Understanding elementary teacher motivations for science fieldtrips. Sci. Educ. 2005, 89, 936-955. [CrossRef]

16. Storksdieck, M. Differences in teachers' and students' museum field-trip experiences. Visit. Stud. Today 2001, 4, 8-12.

17. Bobick, B.; Hornby, J. Practical Partnerships: Strengthening the Museum-School Relationship. J. Museum Educ. 2013, 38, 81-89. [CrossRef]

18. Larsen, Y.C.; Buchholz, H.; Brosda, C.; Bogner, F.X. Evaluation of a portable and interactive augmented reality learning system by teachers and students. Augment. Real. Educ. 2011, 2011, 47-56.

19. Jones, A.C.; Scanlon, E.; Clough, G. Mobile learning: Two case studies of supporting inquiry learning in informal and semiformal settings. Comput. Educ. 2013, 61, 21-32. [CrossRef]

20. Jang, H.; Reeve, J.; Deci, E.L. Engaging Students in Learning Activities: It is Not Autonomy Support or Structure but Autonomy Support and Structure. J. Educ. Psychol. 2010, 102, 588-600. [CrossRef]

21. Cheon, S.H.; Reeve, J.; Vansteenkiste, M. When teachers learn how to provide classroom structure in an autonomy-supportive way: Benefits to teachers and their students. Teach. Teach. Educ. 2020, 90, 103004. [CrossRef]

22. Cox-Petersen, A.M.; Marsh, D.D.; Kisiel, J.; Melber, L.M. Investigation of guided school tours, student learning, and science reform recommendations at a museum of natural history. J. Res. Sci. Teach. 2003, 40, 200-218. [CrossRef] 
23. Kisiel, J.F. Examining teacher choices for science museum worksheets. J. Sci. Teach. Educ. 2007, 18, $29-43$. [CrossRef]

24. Aloe, A.M.; Shisler, S.M.; Norris, B.D.; Nickerson, A.B.; Rinker, T.W. A multivariate meta-analysis of student misbehavior and teacher burnout. Educ. Res. Rev. 2014, 12, 30-44. [CrossRef]

25. Glackin, M. Control must be maintained: Exploring teachers' pedagogical practice outside the classroom. Br. J. Sociol. Educ. 2018, 39, 61-76. [CrossRef]

26. McManus, P.M. Topics in museums and science education. Stud. Sci. Educ. 1992, 20, 157-182. [CrossRef]

27. Ramey-Gassert, L.; Walberg, H.J.; Walberg, H.J. Reexamining connections: Museums as science learning environments. Sci. Educ. 1994, 78, 345-363. [CrossRef]

28. Falk, J.H. Testing a museum exhibition design assumption: Effect of explicit labeling of exhibit clusters on visitor concept development. Sci. Educ. 1997, 81, 679-687. [CrossRef]

29. Kirschner, P.A.; Sweller, J.; Clark, R.E. Why minimal guidance during instruction does not work: An analysis of the failure of constructivist, discovery, problem-based, experiential, and inquiry-based teaching. Educ. Psychol. 2006, 41, 75-86. [CrossRef]

30. Mayer, R.E. Should There Be a Three-Strikes Rule against Pure Discovery Learning? The Case for Guided Methods of Instruction. Am. Psychol. 2004, 59, 14-19. [CrossRef]

31. Sweller, J.; Kirschner, P.A.; Clark, R.E. Why minimally guided teaching techniques do not work: A reply to commentaries. Educ. Psychol. 2007, 42, 115-121. [CrossRef]

32. Alfieri, L.; Brooks, P.J.; Aldrich, N.J.; Tenenbaum, H.R. Does Discovery-Based Instruction Enhance Learning? J. Educ. Psychol. 2011, 103, 1-18. [CrossRef]

33. Ames, C. Classrooms: Goals, structures, and student motivation. J. Educ. Psychol. 1992, 84, 261. [CrossRef]

34. Fantuzzo, J.W.; King, J.A.; Heller, L.R. Effects of Reciprocal Peer Tutoring on Mathematics and School Adjustment: A Component Analysis. J. Educ. Psychol. 1992, 84, 331-339. [CrossRef]

35. Ryan, R.M.; Stiller, J. The social contexts of internalization: Parent and teacher influences on autonomy, motivation, and learning. Adv. Motiv. Achiev. 1991, 7, 115-149.

36. Stipek, D.J. Motivation and instruction. Handb. Educ. Psychol. 2013, 1, 85-113.

37. Bamberger, Y.; Tal, T. Learning in a personal context: Levels of choice in a free choice learning environment in science and natural history museums. Sci. Educ. 2007, 91, 75-95. [CrossRef]

38. Bamberger, Y.; Tal, T. An experience for the lifelong journey: The long-term effect of a class visit to a science center. Visit. Stud. 2008, 11, 198-212. [CrossRef]

39. DeWitt, J.; Hohenstein, J. School trips and classroom lessons: An investigation into teacher-student talk in two settings. J. Res. Sci. Teach. 2010, 47, 454-473. [CrossRef]

40. Jarvis, T.; Pell, A. Factors influencing elementary school children's attitudes toward science before, during, and after a visit to the UK National Space Centre. J. Res. Sci. Teach. 2005, 42, 53-83. [CrossRef]

41. Tal, R.; Bamberger, Y.; Morag, O. Guided school visits to natural history museums in Israel: Teachers' roles. Sci. Educ. 2005, 89, 920-935. [CrossRef]

42. Randler, C.; Bogner, F.X. Cognitive achievements in identification skills. J. Biol. Educ. 2006, 40, 161-165. [CrossRef]

43. Deci, E.L.; Ryan, R.M.; Williams, G.C. Need satisfaction and the self-regulation of learning. Learn. Individ. Differ. 1996, 8, 165-183. [CrossRef]

44. Baumeister, R.F.; Leary, M.R. The need to belong: Desire for interpersonal attachments as a fundamental human motivation. Psychol. Bull. 1995, 117, 497-529. [CrossRef] [PubMed]

45. Deci, E.L.; Ryan, R.M. The "what" and "why" of goal pursuits: Human needs and the self-determination of behavior. Psychol. Inq. 2000, 11, 227-268. [CrossRef]

46. Deci, E.L.; Ryan, R.M. Facilitating optimal motivation and psychological well-being across life's domains. Can. Psychol. 2008, 49, 14-23. [CrossRef]

47. Grolnick, W.S.; Ryan, R.M. Parent Styles Associated with Children's Self-Regulation and Competence in School. J. Educ. Psychol. 1989, 81, 143-154. [CrossRef]

48. Wang, M.T.; Peck, S.C. Adolescent educational success and mental health vary across school engagement profiles. Dev. Psychol. 2013, 49, 1266-1276. [CrossRef] [PubMed]

49. Connell, J.P. Context, self, and action: A motivational analysis of self-system processes across the life span. Self Transit. Infancy Child. 1990, 8, 61-97. 
50. Zimmerman, B.J. Self-Regulated Learning and Academic Achievement: An Overview. Educ. Psychol. 1990, 25, 3-17. [CrossRef]

51. Voelkl, K.E. Identification with school. Am. J. Educ. 1997, 105, 294-318. [CrossRef]

52. Gillies, R.M. Cooperative learning: Review of research and practice. Aust. J. Teach. Educ. 2016, 41, 39-54. [CrossRef]

53. Topping, K.; Buchs, C.; Duran, D.; Van Keer, H. Effective Peer Learning: From Principles to Practical Implementation; Routledge: London, UK; New York, NY, USA, 2017; pp. 1-185.

54. Leung, K.C. An updated meta-analysis on the effect of peer tutoring on tutors' achievement. Sch. Psychol. Int. 2019, 40, 200-214. [CrossRef]

55. Tenenbaum, H.R.; Winstone, N.E.; Leman, P.J.; Avery, R.E. How Effective Is Peer Interaction in Facilitating Learning? A Meta-Analysis. J. Educ. Psychol. 2019, 112, 1303-1319. [CrossRef]

56. Harris, K.R.; Friedlander, B.D.; Saddler, B.; Frizzelle, R.; Graham, S. Self-monitoring of attention versus self-monitoring of academic performance: Effects among students with ADHD in the general education classroom. J. Spec. Educ. 2005, 39, 145-156. [CrossRef]

57. Lan, W.Y. The effects of self-monitoring on students' course performance, use of learning strategies, attitude, self-judgment ability, and knowledge representation. J. Exp. Educ. 1996, 2, 101-115. [CrossRef]

58. Brown, C.C.; Topping, K.J.; Henington, C.; Skinner, C.H. Peer monitoring of learning behaviour: The case of 'Checking chums'. Educ. Psychol. Pract. 1999, 15, 174-182. [CrossRef]

59. Zimmerman, B.J.; Schunk, D.H. Handbook of Self-Regulation of Learning and Performance; Routledge/Taylor \& Francis Group: London, UK; New York, NY, USA, 2011.

60. Joseph, L.M.; Eveleigh, E.L. A review of the effects of self-monitoring on reading performance of students with disabilities. J. Spec. Educ. 2011, 45, 43-53. [CrossRef]

61. Schulze, M.A. Self-Management Strategies to Support Students with ASD. Teach. Except. Child. 2016, 48, 225-231. [CrossRef]

62. Handa, K.; Noro, F. Effects of Self-Monitoring Package to Improve Social Skill of Students With Autism Spectrum Disorders in Japanese Regular Classrooms. J. Spec. Educ. Res. 2016, 5, 1-10. [CrossRef]

63. Davies, S.; Witte, R. Self-Management and Peer-Monitoring within a group contingency to decrease uncontrolled verbalizations of children with Attention-Deficit/hyperactivity disorder. Psychol. Sch. 2000, 37, 135. [CrossRef]

64. Briesch, A.M.; Briesch, J.M. Meta-analysis of behavioral self-management interventions in single-case research. School Psych. Rev. 2016, 45, 3-18. [CrossRef]

65. Farrell, A.; McDougall, D. Self-Monitoring of Pace to Improve Math Fluency of High School Students with Disabilities. Behav. Anal. Pract. 2008, 1, 26-35. [CrossRef] [PubMed]

66. Henington, C.; Skinner, C.H. Peer-monitoring. In Peer Assisted Learning; Topping, K., Ehly, S., Eds.; Erlbaum: Hillsdale, NJ, USA, 1998; pp. 237-253.

67. Reid, R. Research in self-monitoring with students with learning disabilities: The present, the prospects, the pitfalls. J. Learn. Disabil. 1996, 29, 317-331. [CrossRef] [PubMed]

68. Mooney, P.; Ryan, J.B.; Uhing, B.M.; Reid, R.; Epstein, M.H. A review of self-management interventions targeting academic outcomes for students with emotional and behavioral disorders. J. Behav. Educ. 2005, 14, 203-221. [CrossRef]

69. Skinner, C.H.; Cashwell, T.H.; Skinner, A.L. Increasing tootling: The effects of a peer-monitored group contingency program on students' reports of peers' prosocial behaviors. Psychol. Sch. 2000, 37, 263-270. [CrossRef]

70. Kim, W.; Ok, M.W.; Yoo, Y. The Effects of Self- and Peer-Monitoring in Social Studies Performance of Students with Learning Disabilities and Low Achieving Students. Learn. Disabil. Res. Pract. 2018, 33, 87-98. [CrossRef]

71. Committee of the United Nations. Transforming Our World: The 2030 Agenda for Sustainable Development. New Era Glob. Heal. 2018. [CrossRef]

72. Halder, P.; Pietarinen, J.; Havu-Nuutinen, S.; Pelkonen, P. Young citizens' knowledge and perceptions of bioenergy and future policy implications. Energy Policy 2010, 38, 3058-3066. [CrossRef]

73. Van Dael, M.; Lizin, S.; Swinnen, G.; Van Passel, S. Young people's acceptance of bioenergy and the influence of attitude strength on information provision. Renew. Energy 2017, 107, 417-430. [CrossRef]

74. Radics, R.; Dasmohapatra, S.; Kelley, S.S. Systematic review of bioenergy perception studies. BioResources 2015, 10, 8770-8794. [CrossRef] 
75. Guven, G.; Sulun, Y. Pre-service teachers' knowledge and awareness about renewable energy. Renew. Sustain. Energy Rev. 2017, 80, 663-668. [CrossRef]

76. Anderson, D.; Lucas, K.B. The effectiveness of orienting students to the physical features of a science museum prior to visitation. Res. Sci. Educ. 1997, 27, 485-495. [CrossRef]

77. Dewitt, J.; Osborne, J. Recollections of exhibits: Stimulated- recall interviews with primary school children about science centre visits. Int. J. Sci. Educ. 2010, 32, 1365-1388. [CrossRef]

78. Kollar, I.; Fischer, F.; Hesse, F.W. Collaboration scripts-a conceptual analysis. Educ. Psychol. Rev. 2006, 18, 159-185. [CrossRef]

79. Krombaß, A.; Harms, U. Acquiring knowledge about biodiversity in a museum-Are worksheets effective? J. Biol. Educ. 2008, 42, 157-163. [CrossRef]

80. Bortz, J.; Döring, N. Forschungsmethoden und Evaluation für Human- und Sozialwissenschaftler; Springer: Berlin, Germany, 2015.

81. Oksenholt, S.; Lienert, G.A. Testaufbau und Testanalyse; Beltz: Weinheim, Germany, 1998.

82. Bogner, F.X. The Influence of Short-Term Outdoor Ecology Education on Long-Term Variables of Environmental Perspective. J. Environ. Educ. 1998, 29, 17-29. [CrossRef]

83. Scharfenberg, F.-J.; Bogner, F.X.; Klautke, S. The suitability of external control-groups for empirical control purposes: A cautionary story in science education research. Electron. J. Sci. Educ. 2006, 11, 22-36.

84. Schaal, S.; Bogner, F.X. Human visual perception-Learning at workstations. J. Biol. Educ. 2005, 40, 32-37. [CrossRef]

85. Ryan, R.M. Control and information in the intrapersonal sphere: An extension of cognitive evaluation theory. J. Pers. Soc. Psychol. 1982, 43, 450-461. [CrossRef]

86. Gläser-Zikuda, M.; Fuß, S.; Laukenmann, M.; Metz, K.; Randler, C. Promoting students' emotions and achievement-Instructional design and evaluation of the ECOLE-approach. Learn. Instr. 2005, 15, 481-495. [CrossRef]

87. Meissner, B.; Bogner, F. Enriching students' education using interactive workstations at a salt mine turned science center. J. Chem. Educ. 2011, 88, 510-515. [CrossRef]

88. Field, A. Discovering Statistics Using IBM SPSS Statistics. And Sex and Drugs and Rock'n'Roll; Sage: London, UK, 2014.

89. Wassertheil, S.; Cohen, J. Statistical Power Analysis for the Behavioral Sciences. Biometrics 1970, $26,588$. [CrossRef]

90. Hascher, T. Well-being in school-Why students need social support. Lerning Emot. Influ. Affect. Factors Classr. Learn. 2003, 127-142. [CrossRef]

91. Pekrun, R.; Goetz, T.; Frenzel, A.C.; Barchfeld, P.; Perry, R.P. Measuring emotions in students' learning and performance: The Achievement Emotions Questionnaire (AEQ). Contemp. Educ. Psychol. 2011, 36, 36-48. [CrossRef]

92. Griffin, J.; Symington, D. Moving from task-oriented to learning-oriented strategies on school excursions to museums. Sci. Educ. 1997, 81, 763-779. [CrossRef]

93. Rix, C.; McSorley, J. An investigation into the role that school-based interactive science centres may play in the education of primary-aged children. Int. J. Sci. Educ. 1999, 21, 577-593. [CrossRef]

94. Mortensen, M.F.; Smart, K. Free-choice worksheets increase students' exposure to curriculum during museum visits. J. Res. Sci. Teach. 2007, 44, 1389-1414. [CrossRef]

95. Mccurdy, B.L.; Shapiro, E.S. A Comparison of Teacher-, Peer-, and Self-Monitoring with Curriculum-Based Measurement in Reading Among Students with Learning Disabilities. J. Spec. Educ. 1992, 26, 162-180. [CrossRef]

96. Kent, S.; Wanzek, J.; Swanson, E.A.; Vaughn, S. Team-based learning for students with high-incidence disabilities in high school social studies classrooms. Learn. Disabil. Res. Pract. 2015, 30, 3-14. [CrossRef]

97. King, J.A. Making sense of participatory evaluation practice. New Dir. Eval. 1998, 1998, 57-67. [CrossRef]

98. Scharfenberg, F.J.; Bogner, F.X.; Klautke, S. A category-based video analysis of students' activities in an out-of-school hands-on gene technology lesson. Int. J. Sci. Educ. 2008, 30, 451-467. [CrossRef]

99. Williams, G.C.; Deci, E.L. Internalization of Biopsychosocial Values by Medical Students: A Test of Self-Determination Theory. J. Pers. Soc. Psychol. 1996, 70, 767-779. [CrossRef]

100. Ginsburg-Block, M.D.; Rohrbeck, C.A.; Fantuzzo, J.W. A meta-analytic review of social, self-concept, and behavioral outcomes of peer-assisted learning. J. Educ. Psychol. 2006, 98, 732-749. [CrossRef] 
101. Rohrbeck, C.A.; Ginsburg-Block, M.D.; Fantuzzo, J.W.; Miller, T.R. Peer-assisted learning interventions with elementary school students: A meta-analytic review. J. Educ. Psychol. 2003, 95, 240-257. [CrossRef]

102. Heath, C.; Vom Lehn, D. Configuring "interactivity": Enhancing engagement in science centres and museums. Soc. Stud. Sci. 2008, 38, 65-93. [CrossRef]

103. Falk, J.H.; Dierking, L.D. Learning from Museums: Visitor Experiences and the Making of Meaning, 2nd ed.; Rowman and Littlefield: Lanham, MD, USA, 2000.

104. Price, S.; Hein, G.E. More than a field trip: Science programmes for elementary school groups at museums. Int. J. Sci. Educ. 1991, 13, 505-519. [CrossRef]

105. Ryan, R.M.; Deci, E.L. Self-determination theory and the facilitation of intrinsic motivation, social development, and well-being. Am. Psychol. 2000, 55, 68-78. [CrossRef]

106. Ainley, M. Connecting with learning: Motivation, affect and cognition in interest processes. Educ. Psychol. Rev. 2006, 18, 391-405. [CrossRef]

107. Randler, C. Association Between Emotional Variables and School Achievement. Int. J. Instr. 2009, 2, 3-10.

108. Hidi, S.; Berndorff, D.; Ainley, M. Children's argument writing, interest and self-efficacy: An intervention study. Learn. Instr. 2002, 12, 429-446. [CrossRef]

109. Pekrun, R.; Goetz, T.; Titz, W.; Perry, R.P. Academic emotions in students' self-regulated learning and achievement: A program of qualitative and quantitative research. Educ. Psychol. 2002, 37, 91-105. [CrossRef]

110. Pekrun, R.; Goetz, T.; Daniels, L.M.; Stupnisky, R.H.; Perry, R.P. Boredom in Achievement Settings: Exploring Control-Value Antecedents and Performance Outcomes of a Neglected Emotion. J. Educ. Psychol. 2010, 102, 531-549. [CrossRef]

111. Dewey, J. Logic: The Theory of Inquiry. John Dewey: The Latter Works; A. Boydston: Carbondale, IL, USA, 1991; Volume 4, pp. 1925-1953.

112. Topping, K.J. Trends in peer learning. Educ. Psychol. 2013, 25, 631-645. [CrossRef]

113. Ryan, R.M.; Stiller, J.D.; Lynch, J.H. Representations of Relationships to Teachers, Parents, and Friends as Predictors of Academic Motivation and Self-Esteem. J. Early Adolesc. 1994, 14, 226-249. [CrossRef]

114. Kubota, C.A.; Olstad, R.G. Effects of novelty-reducing preparation on exploratory behavior and cognitive learning in a science museum setting. J. Res. Sci. Teach. 1991, 28, 225-234. [CrossRef]

115. Rennie, L.J. Learning Science Outside of School Handbook of Research on Science Education; Lawrence Erlbaum Associates: New Jersey, NJ, USA, 2007; pp. 125-167.

116. Sarason, I.G. Stress, anxiety, and cognitive interference: Reactions to tests. J. Pers. Soc. Psychol. 1984, 46, 929-938. [CrossRef]

117. Colley, H.; Hodkinson, P.; Malcom, J. Informality and Formality in Learning: A Report for the Learning and Skills Research Centre; University of Leeds: Leeds, UK, 2004; ISBN 1853389145.

Publisher's Note: MDPI stays neutral with regard to jurisdictional claims in published maps and institutional affiliations.

(C) 2020 by the authors. Licensee MDPI, Basel, Switzerland. This article is an open access article distributed under the terms and conditions of the Creative Commons Attribution (CC BY) license (http://creativecommons.org/licenses/by/4.0/). 